discrepancy in TB incidence rates reported in Norway by HEIMBECK [4] in 1928 and reviewed elsewhere [5]. Additional support for this "threshold effect" is provided by differences in the calculated annual risk of infection observed in two adjacent study communities, where socioeconomic conditions in the area with reduced transmission are sufficiently improved to affect general living conditions [6].

Therefore, from a TB transmission perspective it seems less informative to stratify extreme levels of poverty, and more informative to evaluate whether the available epidemiological evidence supports the existence of a threshold effect. Determination of a threshold effect will guide epidemiological thinking and potentially assist in identifying global poverty alleviation targets. Measuring child TB incidence rates as an epidemiological marker of ongoing transmission could be considered in future analyses, once more reliable WHO data becomes available. MYERS et al. [7] have found lower income, ethnicity and immigration status to be significantly associated with child TB incidence in California, USA.

Effective public health strategies remain critically important, even in the poorest of settings. However, the global distribution of the tuberculosis disease burden bears witness to the fact that extreme inequalities in wealth remain one of the key factors sustaining the tuberculosis epidemic.

\section{B.J. Marais, A.C. Hesseling and M.F. Cotton}

Dept of Paediatrics and Child Health, Desmond Tutu Tuberculosis Research Centre, Faculty of Health Sciences, Stellenbosch University, Tygerberg, South Africa.

\section{STATEMENT OF INTEREST}

None declared.

\section{REFERENCES}

1 Janssens JP, Rieder HL. An ecological analysis of incidence of tuberculosis and per capita gross domestic product. Eur Respir J 2008; 32: 1415-1416.

2 Marais BJ, Obihara CC, Warren RW, Schaaf HS, Gie RP, Donald PR. The burden of childhood tuberculosis: a public health perspective. Int J Tuberc Lung Dis 2005; 9: 1305-1313.

3 Marais BJ, Esser M, Godwin S, Rabie H, Cotton MF. Poverty and HIV in children a view from the Western Cape, South Africa. Ann N Y Acad Sci 2008; 1136: 21-27.

4 Heimbeck J. Tuberkuloseinfektion og tuberkulocevakcination [Tuberculosis infection and vaccination]. Tidsskr Norske Laegeforen 1928; 48: 945-961.

5 Bjarveit K. Olaf Scheele and Johannes Heimbeck: their contribution to understanding the pathogenesis and prevention of TB. Int J Tuberc Lung Dis 2003; 7: 306-311.

6 Kritzinger FE., den Boon S., Verver S., et al. No decrease in annual risk of tuberculosis infection in endemic area in Cape Town, South Africa. Trop Med Int Health 2008; (in press).

7 Myers WP, Westenhouse JL, Flood J, Riley LW. An ecological study of tuberculosis transmission in California. Am J Public Health 2006; 96: 685-690.

\title{
Danger of using an unreliable classification system for preschool wheeze
}

\section{To the Editors:}

The management of preschool children with wheezing disorders remains challenging. Clinicians should, therefore, welcome the decision by the European Respiratory Society to establish a Task Force to address this problem. The Task Force recommends that the terms episodic (viral) wheeze and multitrigger wheeze should be used to describe different clinical phenotypes of preschool wheeze [1]. However, the report acknowledges that there is large overlap in these two phenotypes and that patients can move from one phenotype to another [1]. Therefore, these two phenotypes are a long way from the "clear descriptions of patients" that the report suggests are needed for well-designed randomised controlled trials.

The clinical classification of wheeze phenotypes into episodic (viral) wheeze and multi-trigger wheeze is based on the assumption that wheeze associated with coryzal symptoms is virus induced, while wheeze in the absence of coryzal symptoms is not [2]. However, this fails to take into account the fact that most wheezing symptoms in preschool children are associated with viral infections [3] while, conversely, $>20 \%$ of asymptomatic asthmatic children aged 2-17 yrs test positive for rhinovirus in their respiratory secretions [4]. Basing classification on clinical judgment may therefore be hazardous.

To further complicate matters, for research purposes preschool phenotype classification based on clinical symptoms is usually based on a retrospective parental report $[5,6]$. When classification relies on potentially inaccurate clinical judgment of the presence or absence of viral infection, then adding a retrospective component could only further compromise the accuracy of classification system.

We agree with the authors of the Task Force report that a robust classification system has the potential to advance research and ultimately improve clinical decision making. However, we feel that the proposed classification based on episodic (viral) and multi-trigger wheeze is deeply flawed. Let us not succumb to the lure of this system for want of 
something better. No classification is better than an incorrect classification.

\section{A. Schultz and D. Payne \\ Dept of Paediatric and Adolescent Medicine, Princess Margaret Hospital, Perth, WA, Australia.}

\section{STATEMENT OF INTEREST}

A statement of interest for D. Payne can be found at www.erj.ersjournals.com/misc/statements.shtml

\section{REFERENCES}

1 Brand PL, Baraldi E, Bisgaard H, et al. Definition, assessment and treatment of wheezing disorders in preschool children: an evidence-based approach. Eur Respir J 2008; 32: 1096-1110.

2 McKean M, Ducharme F. Inhaled steroids for episodic viral wheeze of childhood. Cochrane Database Syst Rev 2000; 2: CD001107.

3 Kusel MM, de Klerk NH, Kebadze T, et al. Early-life respiratory viral infections, atopic sensitization, and risk of subsequent development of persistent asthma. J Allergy Clin Immunol 2007; 119: 1105-1110.

4 Khetsuriani N, Kazerouni NN, Erdman DD, et al. Prevalence of viral respiratory tract infections in children with asthma. $J$ Allergy Clin Immunol 2007; 119: 314-321.

5 Silverman M, Wang M, Hunter G, Taub N. Episodic viral wheeze in preschool children: effect of topical nasal corticosteroid prophylaxis. Thorax 2003; 58: 431-434.

6 Kuehni CE, Strippoli MP, Low N, Brooke AM, Silverman M. Wheeze and asthma prevalence and related health-service use in white and south Asian pre-schoolchildren in the United Kingdom. Clin Exp Allergy 2007; 37: 1738-1746.

DOI: $10.1183 / 09031936.00172608$

\section{From the authors:}

We thank A. Schultz and D. Payne for their interest in the Task Force report, and agree that the current classification system for preschool wheeze [1] may not be without flaws. Neither is their letter, however.

For any classification to be of present clinical use, phenotypes have to be determined at the time the child is seen; thus, "transient" and "persistent" [2] are of no use clinically, although of great value epidemiologically. In current clinical practice, the description of symptoms, imperfect although this is, remains the bedrock of clinical decision making. This is particularly true in preschool children with recurrent wheeze in whom it is difficult to obtain more objective measures of airways obstruction. It is surely not beyond a clinician to determine if a child has acute bouts of wheeze in association with coryzal symptoms, with symptom-free periods in between, or has wheeze most days of the week, exacerbating with clinically apparent upper respiratory tract infections.
Although it may not be possible to be sure that any individual acute episode of preschool wheeze is due to a viral infection, and this is why the term "viral" is in parentheses, the evidence is that the vast majority is viral in origin. The fact that viruses can be found in some nonwheezy children is acknowledged, but in our view this is not relevant to the classification. Accumulating evidence suggests that children with episodic treatment may be treated episodically [3-6]. It would be preferable of course to phenotype using practical, robust and clinically available biomarkers, but none presently exist. The alternative is to treat the nonatopic 3-yr-old with five episodes of acute wheeze a year, with no interval symptoms, in exactly the same way as an atopic child of the same age with exacerbations superposed on a pattern of daily symptoms, which appears to be the consequence of A. Schultz's and D. Payne's position. After lengthy discussion, the majority of the Task Force felt that the present classification system should be presented and maintained, along with the limitations of the system.

\section{A. Bush* and P.L.P. Brand}

*Dept of Paediatric Pulmonology, Royal Brompton Hospital, London, UK, and "Princess Amalia Children's Clinic, Isala Klinieken, Zwolle, The Netherlands.

\section{STATEMENT OF INTEREST}

None declared.

\section{REFERENCES}

1 Brand PL, Baraldi E, Bisgaard H, et al. Definition, assessment and treatment of wheezing disorders in preschool children: an evidence-based approach. Eur Respir J 2008; 32: 10961110.

2 Martinez FD, Wright AL, Taussig LM, Holberg CJ, Halonen M, Morgan WJ. Asthma and wheezing in the first six years of life: the Group Health Medical Associates. $N$ Engl J Med 1995; 332: 133-138.

3 McKean M, Ducharme F. Inhaled steroids for episodic viral wheeze of childhood. Cochrane Database Syst Rev 2000; 2: CD001107.

4 Ducharme FM, Lemire C, Nova FJ, et al. Preemptive use of high-dose fluticasone for virus-induced wheezing in young children. N Engl J Med 2009; 360: 339-353.

5 Robertson CF, Price DA, Henry R, et al. Short-course montelukast for intermittent asthma in children: a randomized controlled trial. Am J Respir Crit Care Med 2007; 175: 323-329.

6 Bacharier LB, Phillips BR, Zeiger RS, et al. Episodic use of an inhaled corticosteroid or leukotriene receptor agonist in preschool children with moderate-to-severe intermitent wheezing. J Allergy Clin Immunol 2008; 122: 1127-1135.

DOI: $10.1183 / 09031936.00179908$ 